\title{
Sobre escravidão e imigração: relações interétnicas
}

\author{
About slavery and immigration: interethnic relations \\ Sobre esclavitud y inmigración: relaciones interétnicas
}

MarcosAntonio Witt*

\section{Resumo}

O presente texto tem como objetivo estabelecer diálogo entre dois temas relevantes da historiografia brasileira - escravidão e imigração - no âmbito das relações interétnicas. Ao comprar e fazer uso da mão de obra escrava, imigrantes alemães e descendentes equipararam-se à elite nacional, pois possuir escravos concedia status na sociedade oitocentista. Rompendo com parte da historiografia sobre imigração, a qual afirma que imigrantes não haviam trabalhado com cativos em suas propriedades, quer-se demonstrar que aspectos econômicos, políticos e sociais perpassaram a compra e venda e a manutenção de escravos em propriedades rurais e urbanas dos imigrantes. Inventários, processos-crime, escrituras de compra e venda e registros elaborados por padres e pastores constituem-se em fontes importantes para o estudo das relações interétnicas entre escravos e imigrantes alemães.

Palavras-chave: Escravidão. Imigração. Relações interétnicas. Século XIX.
A historiografia sobre imigração no Brasil pode ser classificada em vários grupos: acadêmicos e não acadêmicos; clássicos; científicos. Dificilmente esses conceitos expressam a totalidade de uma obra, pois, em algumas situações, a mesma obra poderá reunir características que a definam como clássica e acadêmica. Esse é o caso de "A colonização alemã e o Rio Grande do Sul", de Jean Roche. Escrita em dois volumes, em

\footnotetext{
Professor no Programa de Pós-Graduação em História da Universidade do Vale do Rio dos Sinos (Unisinos); coordenador do Núcleo de Estudos Teuto-Brasileiros (NETB), vinculado a essa mesma Universidade; doutor em História pela Pontifícia Universidade Católica do Rio Grande do Sul (PUCRS); associado ao Instituto Histórico de São Leopoldo e à Associação Nacional de Pesquisadores da História das Comunidades Teuto-Brasileiras; coordenador da área de História do Programa Institucional de Bolsas de Iniciação à Docência (Pibid/Capes), desenvolvido no curso de graduação em História da Unisinos; pesquisa os temas política, imigração, Brasil império.E-mail: mawitt@unisinos.br.
}

Recebido em 19/07/2013 Aprovado em 30/07/2013 http://dx.doi.org/10.5335/hdtv.14n.1.3352 
ambiente acadêmico, tornou-se um dos clássicos mais consultados no que tange aos estudos sobre e/i/migração. De igual modo, a historiografia sobre imigração - não importando o grupo analisado, se alemão, italiano, polonês - tornou-se bastante conhecida por meio das obras que destacam a contribuição dos imigrantes e de seus descendentes para uma cidade, região, província/estado e/ou mesmo para o Brasil. Via de regra, são textos não acadêmicos que engrandecem a figura do pioneiro e de suas façanhas a partir da chegada ao Brasil. Em muitos desses escritos, o colono e sua colônia ${ }^{1}$ parecem estar desconectados do restante da realidade. É como se vivessem somente para a família e a localidade onde estão inseridos. É como se estivessem isolados do restante do Brasil.

Os escritos que privilegiam essa abordagem quase nunca se dedicam a analisar a relação que os imigrantes e seus descendentes estabeleceram com os outros ${ }^{2}$ - nacionais (de origem portuguesa e açoriana) e escravos (de origem africana). ${ }^{3}$ Se uma pequena passagem do texto ou do livro menciona o contato de um imigrante com um vizinho nacional, ou mesmo com um escravo, essa narrativa muitas vezes beira o anedótico e/ ou o exótico. Portanto, as relações interétnicas deixam de estar no horizonte dos autores/pesquisadores que escreveram sobre o início de uma Picada ${ }^{4}$ ou Colônia, as primeiras dificuldades com a mata, os animais ferozes e os índios, a construção da igreja e da escola, as primeiras colheitas e o sucesso após longos anos de labuta. Partindo-se dessa ótica, imigrantes e descendentes teriam construído suas vidas praticamente sozinhos, envoltos em um ambiente familiar, dialogando somente com seus pares e privilegiando unicamente as estruturas religiosas e educacionais.

Estudos recentes, sobretudo os formatados a partir de pesquisas realizadas no âmbito dos programas de pós-graduação (PPGs), romperam com esse modelo de análise. Com a década de 1990, o Brasil viu ampliada a sua rede de PPGs. Afora outras contribuições, os programas incentivaram as pesquisas e o acesso a novas fontes. Com mestrandos e doutorandos visitando novos e velhos arquivos, o mundo das relações interétnicas tornou-se um dos temas que contribuíram significativamente para os estudos da imigração. Inventários; processos-crime; escrituras de compra e venda; registros de nascimento, batismo, casamento e óbito; registros paroquiais da Lei de Terras e mais um número expressivo de documentos possibilitaram que o pesquisador mapeasse a relação que os imigrantes e seus descendentes estabeleceram com os outros.

As considerações iniciais do presente texto abordam aspectos gerais da historiografia sobre imigração. Como objetivo maior, tem-se a intenção de aproximar dois grandes temas - escravidão e imigração para, a partir dessa aproximação, analisar a relação que imigrantes alemães ${ }^{5}$ e descendentes estabeleceram com escravos ao longo do século XIX. Investigando esse tema desde 1998, foi possível constatar que o vínculo mantido entre imigrantes alemães e escravos representaria avanços no estudo das relações interétnicas. Uma primeira questão é a posse de escravos por parte de imigrantes e descendentes; um segundo aspecto é o rompimento definitivo com a tese do isola- 
mento. Esses dois fatores permitiram que o pesquisador vislumbrasse um mundo imigrante que se distanciava daquele representado pela historiografia laudatória.

Comprar e vender escravos tinha implicações econômicas, políticas e sociais. Do ponto de vista econômico, significava ter recursos suficientes para adquirir esse tipo de mão de obra; em termos políticos, demonstrava percepção da realidade e condições de dialogar com as autoridades locais; do ponto de vista social, significava equiparar-se com os vizinhos nacionais. Em outras palavras, ter escravos proporcionava agigantamento econômico e projeção político-social - leia-se status. Tratando-se de imigrantes, deve-se duvidar da falsa ideia de que essas famílias buscaram somente uma alternativa para aumentar o número de braços trabalhadores depois de décadas de permanência em solo brasileiro. A documentação e os estudos produzidos em determinados ambientes de pesquisa evidenciam que os imigrantes, desde a sua imediata chegada ao Brasil, perceberam o valor material e imaterial da posse de escravos em suas propriedades rurais e/ou urbanas.

No entanto, o mesmo grupo historiográfico que cristalizou a ideia de que os imigrantes haviam proporcionado relevante contribuição para o desenvolvimento do Brasil apagou, silenciou a presença de outros na vida desses imigrantes. Por essa lógica, a contribuição somente poderia ser destacável se o trabalhador branco europeu trazido ao Brasil pela vontade do império construísse um novo mundo a partir do uso exclusivo das suas mãos. Isto é, o colono alemão havia se dobrado sob o sol inclemente dos trópicos e, com suas mãos, produzido a riqueza da casa, da Colônia e da região por onde seus produtos circulavam. Partindo-se dessa premissa, os outros não tinham espaço nessa pesquisa e análise. Tomando-se a contribuição do imigrante como algo isolado, os escravos jamais se fariam presentes no mundo imigrantista. Portanto, foi preciso visitar arquivos, folhear novas fontes, ou fazer novas perguntas para fontes já consultas, a fim de que outros agentes históricos compusessem o cenário imigrantista do Brasil.

Em termos de produção historiográfica, no início da década de 1980, Margaret Bakos e Helga Piccolo produziram textos sobre a posse de escravos por parte de famílias alemãs. De certa forma, podem ser interpretados como textos pioneiros quanto à relação dos imigrantes com escravos. Talvez ainda fosse muito cedo para a academia dedicar-se a tema tão original e delicado. Afinal, parte da historiografia da imigração alemã afirmava, veementemente, que os imigrantes não haviam possuído escravos em suas propriedades. Telmo Lauro Müller, ao aceitar a presença de negros entre imigrantes, afirmou que os trabalhadores - escravos - seriam tão bem tratados pelos imigrantes - proprietários - que falariam o idioma alemão. Do mesmo modo que a renovação historiográfica lançou novos olhares sobre a questão da participação política dos imigrantes, novas pesquisas no âmbito da escravidão romperam com a falsa ideia de que somente os trabalhadores brancos, livres, de origem europeia teriam revirado a terra com suas mãos.

A partir dos textos produzidos por Bakos e Piccolo e através dos PPGs e do aces- 
so a novas fontes, como inventários, processos-crime e escrituras de compra e venda, foi possível aproximar os temas escravidão e imigração. Investindo sobre novas fontes ou revisitando e/ou fazendo novas perguntas a fontes já conhecidas, derrubou-se um dos grandes mitos em relação à imigração. A afirmação categórica de que somente o trabalho dos colonos alemães havia produzido o progresso de determinada região e, por consequência, da província e do Estado do Rio Grande do Sul passou por certos estremecimentos quando os inventários e as escrituras de compra e venda revelaram o uso da mão de obra escrava nas propriedades agrícolas e nos estabelecimentos comerciais rurais e urbanos.

Martin Dreher, em texto publicado em 1995, chamou a atenção para as leis que impediam os colonos de possuir escravos em suas propriedades agrícolas. De fato, império e província preocuparam-se com a possibilidade de os colonos adquirirem escravos para executar as mais inúmeras atividades. A razão dessa preocupação estaria no fato de que os imigrantes e seus descendentes, sobretudo aqueles que se tornaram colonos - agricultores -, deveriam ocupar o território, produzir alimentos, dinamizar o mercado interno e criar uma força de oposição aos grandes fazendeiros. Estes, muitas vezes, em razão de suas grandes propriedades e da manutenção de milícias particulares, colocavam-se contra, não raro em guerra, o império brasileiro. Caso os colonos agigantassem seus investimentos econômicos, os objetivos propostos com a imigração poderiam não ser alcançados.
Com esse receio, império e província promulgaram leis que tentaram impedir o uso de escravos nas Colônias alemãs. Porém, os imigrantes e seus descendentes muito rapidamente perceberam que possuir escravos poderia representar crescimento econômico, projeção política e obtenção de status junto à sociedade hospedeira. Dreher, mesmo produzindo seu texto em 1995, quando as pesquisas que relacionam imigração e escravidão começaram a despontar, ao mencionar as referidas leis, deixou de considerar que os colonos poderiam burlar as normas e encontrar meios para alavancar seus investimentos. Quando se investigaram as Colônias alemãs do Litoral Norte do Rio Grande do Sul, foi possível perceber que São Pedro de Alcântara e Três Forquilhas também estavam impedidas por lei de fazer uso de mão de obra cativa nas propriedades dos colonos. Contudo, as fontes denunciaram e demonstraram exatamente o oposto; isto é, os colonos que tiveram recursos compraram e usufruíram do trabalho escravo em suas lavouras, casas e comércio (WITT, 2001). Portanto, apesar de haver conhecimento sobre a publicação da lei proibitiva, os colonos encontram alternativas para tentar agigantar suas produções e seus negócios.

Felipe Kuhn Braun, em obra recente, também faz menção às leis que impediam o uso de escravos nas colônias. No entanto, mesmo aceitando que "muitos alemães descumpriam a regra", o autor justifica esse descumprimento "porque [os imigrantes] precisavam de pessoas que lhes ajudassem no trabalho diário" (BRAUN, 2010, p. 50). No que concerne à convivência, Braun afirma que 
[...] a relação entre o alemão e o negro, embora fosse preconceituosa na maioria das vezes, se dava de uma forma muito mais familiar à do português com o negro. Alguns escravos ganharam também os sobrenomes de seus patrões alemães (2010, p. 51).

As novas pesquisas que têm aproximado escravidão e imigração relativizam as afirmações de Braun. Tanto as fontes como os trabalhos que as têm analisado apontam para um total pragmatismo na compra e venda de escravos por parte dos alemães. Imigrantes urbanos e rurais obtiveram escravos e os utilizaram em suas casas e em seus negócios. Portanto, não se trata de ajuda, e sim de investimento. Afora isso, o fato de o escravo falar um dos dialetos alemães é consequência do convívio, e não de um suposto aprazível dia a dia entre proprietário e escravo. Assim como Müller, o autor defende que o cotidiano experimentado por esses dois agentes históricos seria mais amistoso do que o vivenciado por um escravo na companhia de seu senhor de origem portuguesa. Novamente, as fontes e as pesquisas, sobretudo os processos-crime, denunciam o uso de castigos para a coerção e obtenção da disciplina. Pelos estudos, é possível perceber que o elemento africano escravizado recebeu o mesmo tipo de tratamento tanto do proprietário de origem portuguesa quanto do senhor de origem alemã. A tradição oral, composta por inúmeras histórias de maus tratos recolhidas nas Colônias, como castigos violentos e mesmo mortes, ratifica o que ficou registrado nas fontes escritas.

No que tange à questão do investimento, defende-se a ideia de que o uso de mão de obra escrava por parte dos colonos alemães pode ser interpretado como atividade econômica. Comprar, manter e vender escravos fez parte do cotidiano de alguns "exponenciais", 6 os quais otimizaram o desempenho de suas propriedades a partir da exploração de trabalhadores cativos. Afora desejar o crescimento econômico, os "exponenciais" que usaram mão de obra escrava estavam buscando a tão almejada inserção social que esse recurso poderia proporcionar-lhes. Desse modo, dispor de escravos para executar tarefas dos mais variados tipos auxiliava na equiparação dos "exponenciais" com seus vizinhos nacionais. Inclusive, pastores ${ }^{7}$ foram proprietários de escravos, como Carlos Leopoldo Voges, ${ }^{8}$ de Três Forquilhas, RS, e Friedrich Oswald Sauerbronn, de Nova Friburgo, RJ. De acordo com Roland Spliesgart, Sauerbronn também batizou escravos em sua comunidade, procedendo de modo semelhante ao do seu colega Voges. Contudo, nem todos os líderes religiosos aprovavam a escravidão. Segundo Spliesgart, o pastor Hollerbach, de Teófilo Otoni, MG, posicionou-se contra o uso de mão de obra cativa. Apesar das constantes lamentações de Sauerbronn sobre o seu estado de pobreza e o da maioria dos colonos de Nova Friburgo, segundo o autor, $15 \%$ das famílias da comunidade de Nova Friburgo possuíam escravos em suas propriedades. $^{9}$

Já na província do Rio Grande do Sul, na Colônia de São Leopoldo, de acordo com o Livro de registros I da comunidade evangélica de Hamburgo Velho, ${ }^{10}$ o casal Jakob e Elisabeth Diefenthäler batizou e foi padrinho dos seguintes filhos de escravas: 
- Maria Diefenthaeler, nascida em 7/2/1850, batizada em 24/2/1850.

- Joseph Diefenthaeler, nascido em 20/3/1854, batizado em 23/4/1854.

- João Diefenthaeler, nascido em 23/9/1856, batizado em 14/12/1856.

- Adão Diefenthaeler, nascido em 24/12/1859, batizado em 26/2/1860.

- Luiz Diefenthaeler, nascido em 24/1/1862, batizado em 23/5/1862.

- Carlos Diefenthaeler, nascido em 14/1/1866, batizado em 1/4/1866.

Segundo essa mesma fonte, o irmão de Jakob, Peter Diefenthäler, casado com Karoline Reichert, também se tornou proprietário de escravos, tendo o casal batizado e apadrinhado as seguintes crianças, filhos de suas escravas:

- Rose Diefenthaeler, nascida em 6/7/1865, batizada em 3/9/1865.

- Anna Maria Diefenthaeler, nascida em $7 / 1 / 1866$, batizada em 25/2/1866.

- José Diefenthaeler, nascido em 9/7/1868, batizado em 18/10/1868.

- João Diefenthaeler, nascido em 29/1/1870, batizado em 5/6/1870.

- Adão José Diefenthaeler, nascido em 3/8/1871, batizado em 22/10/1871.

- Eva Diefenthaeler, nascida em 29/9/1873, batizada em 30/11/1873, filha nascida livre da escrava Luiza. Padrinhos: Frederico e Theresia de Quadro.

Os registros realizados pelo pastor Johann Peter Haesbaert constituem-se em prova incontestável de que ambos os casais possuíram escravos em suas propriedades. Em todos os batismos, com exceção do de Eva, realizado em 30 de novembro de 1873, Jakob e Peter seguiram o costume de apadrinhar os batizandos, filhos de suas escravas. A atitude do pastor Haesbaert, da comunidade evangélica de Hamburgo Velho, pode ser comparada à de seus colegas Sauerbronn e Voges, os quais igualmente registraram batizados de escravos em seus assentamentos eclesiásticos. Com esses registros, não somente os temas escravidão e imigração são aproximados, como também os imigrantes alemães e seus descendentes são inseridos na lógica social do século XIX. Nem mesmo os pastores deixaram de ser agentes históricos do seu tempo; isto é, valores como moral não se colocaram como empecilhos para a posse de escravos. Afinal, poder comprar e usufruir de mão de obra cativa os identificava como "exponenciais" nos campos político, econômico e social.

Contudo, padres e pastores não foram os únicos a efetuar registros que, com o passar dos anos e séculos, tornaram-se fonte para os estudiosos da escravidão e imigração. Comerciantes, também identificados como vendeiros, confeccionaram fonte relevante para a temática das relações interétnicas. Trata-se do livro-caixa, no qual o freguês (cliente) possuía uma conta corrente dividida entre as colunas "deve" e "haver". Em um livro" de uma venda da Colônia de Três Forquilhas, encontra-se o registro de "Affonso Voges", o qual foi identificado com a palavra "negro" (página 279, ano 1891). Ao cruzar essa fonte com o inventário de Guilhermina Voges, foi possível localizar no rol dos escravos o nome de Affonso, avaliado em $650 \$ 000$, caracterizado como lavrador, com 44 anos, em $1880{ }^{12}$ É possí- 
vel que se trate do escravo que pertencia ao casal Adolpho e Guilhermina Voges, da Colônia de Três Forquilhas. Do mesmo modo como ocorreu nos batismos celebrados pela família Diefenthäler, descritos e analisados acima, o ex-escravo Affonso trazia consigo o sobrenome do ex-senhor.

$\mathrm{O}$ registro efetuado pelo vendeiro permite algumas considerações, pois não somente comprova o fato de que a comunidade negra, liberta fazia parte do cenário colonial, como também vincula o liberto à família Voges. Nesse caso específico, o ex-escravo foi batizado com o nome e o sobrenome do ex-senhor, o que o conecta diretamente ao núcleo familiar "exponencial" - Voges - e sugere que, de escravo, esse agente histórico migrou para a condição de freguês, uma vez que estava no rol dos clientes daquela casa comercial. A vida de Affonso Voges, em poucas linhas, permite o mapeamento de parte da trajetória experimentada pelos escravos que integraram o cenário econômico-social das colônias alemãs. Com a metodologia empregada por Vinícius de Oliveira, que em sua dissertação de mestrado mapeou a vida e os percalços do escravo Manoel Congo, poder-se-ia investigar e trazer à luz novos dados sobre a trajetória de Affonso Voges.

O mapeamento social apresentado e discutido por meio dos casos mencionados nas linhas anteriores é fruto da análise de relações de parentesco e de amizade entre famílias que se destacaram no cenário colonial do Rio Grande do Sul. Em termos de documentação, os inventários contribuíram para a análise da escravidão e das redes sociais estabelecidas pelos colonos e seus descen- dentes entre os pares, mas também com os nacionais. Inventários e outros documentos costurados a eles trouxeram à luz o potencial econômico dos colonos, ao registrarem a quais atividades as famílias se dedicavam, sugerindo que o enriquecimento deu-se pela ampliação dos negócios, os quais envolveram compra e venda de terras, comércio (estabelecimento comercial, venda), empréstimo de dinheiro e uso de mão de obra escrava. Com os inventários, foi possível constatar que muitos dos colonos que possuíram escravos se dedicaram, ainda, a múltiplas atividades econômicas. Segundo Giovanni Levi, "a diversificação das atividades e a sua inserção em uma estratégia mais ampla misturaram a administração econômica com as relações sociais, criando interligações muitas vezes complexas" (2000, p. 112).

Em termos de números, segundo Ernesto Pellanda, em 1850, havia 229 escravos na Colônia de São Leopoldo, o que se considerava "número demasiado grande num distrito [em] que se pode dispor de tantos braços livres"; porém, vinte anos depois dessa contagem, o número de escravos na Colônia subiu para $1.060 .{ }^{13} \mathrm{~A}$ fim de buscar subsídios para essa análise, foram consideradas as estimativas apresentadas por Helen Osório e Luís Augusto Ebling Farinatti. Para Osório, cujo levantamento refere-se ao período de 1765 a 1825, a maioria dos proprietários de escravos no Rio Grande do Sul possuía, no mínimo, nove peças. Esse número se eleva quando a autora contabiliza a média dos escravos que trabalhavam nas charqueadas: 40 peças por empresa. Se esse número for comparado com os dados referentes aos engenhos de açúcar, percebe-se que a dife- 
rença entre os plantéis das charqueadas e os dos engenhos não é abismal. De acordo com Osório, os senhores de engenho possuíam, em média, 66 escravos. Talvez o dado mais relevante apresentado pela autora seja o de que apenas sete proprietários do meio rural do Rio Grande do Sul possuíam 50 escravos ou mais.

Da mesma forma, Farinatti realizou levantamento demográfico sobre a população escrava do município de Alegrete, no período de 1831 a 1870 . Nessa localidade, em 1858, 391 estâncias possuíam 527 escravos, sendo a média de 1,34 por unidade produtiva. Em outra tabela, que sintetiza os dados sobre escravos com ocupações declaradas (entre 1831-1850), o autor localizou 337 escravos em 74 inventários, o que resulta na média de 4,55 por documento. Ambos os autores tiveram como objeto de investigação os inventários. Apesar de suas análises estarem concentradas nessa documentação, elas procuram dar conta do universo rio-grandense e platino na virada do século XVIII para o XIX e no transcorrer deste último. Se, por um lado, as citações previamente selecionadas e constantes neste trabalho não refletem todo o arcabouço pesquisado e defendido por Osório e Farinatti, elas colaboram para que se possa redimensionar a potencialidade econômica dos imigrantes e de seus descendentes.

Portanto, para os imigrantes "exponenciais", política e economia não estavam dissociadas; para imigrantes e descendentes, que abriram espaço no meio político, o crescimento e a consolidação econômica equiparavam-nos aos vizinhos nacionais. Isso explica por que alemães tornaram-se proprietários de escravos. Ângela Sperb trabalhou o inventário de um desses colonos que considerou a inserção política e a diversidade econômica como espaços possíveis de atuação. João Pedro Schmitt instalou-se em uma localidade denominada de Costa da Serra, onde abriu uma venda. A fortuna de Schmitt, em 1868, chegou aos 85:005\$510, distribuída entre estabelecimento comercial (venda), empréstimo, casas, terras, plantel de onze escravos e animais para criação e auxílio no transporte de mercadorias (SPERB, 1987, p. 17-44).

A dimensão dos negócios de Schmitt equipara-se à dos "exponenciais" analisados neste trabalho, sobretudo a diversificação dos investimentos e a opção de ter a venda como suporte econômico. Nesse caso específico, o comércio de Schmitt serve como parâmetro e indicador de que a Costa da Serra era, de fato, um ponto comercial que se destacava no cenário colonial expandido a partir de São Leopoldo. Schmitt, conforme listagem levantada por Germano Moehlecke, constava como um dos grandes proprietários de escravos da Colônia de São Leopoldo, fato respaldado pela pesquisa efetuada por Sperb, que mostra que, em seu inventário, constavam onze escravos. O plantel de escravos, abaixo nominado, representava 13,4\% do patrimônio de Schmitt:

- Manoel, da nação Nagô, 55 anos de idade, $200 \$ 000$ (duzentos mil réis).

- João, crioulo, 26 anos, 1:800\$000 (um conto e oitocentos mil réis).

- Manoel, crioulo, 16 anos, 1:500\$000 (um conto e quinhentos mil réis).

- José, crioulo, 25 anos, 1:500\$000 (um conto e quinhentos mil réis). 
- Guilherme, 14 anos, 1:400\$000 (um conto e quatrocentos mil réis).

- Antônio, 12 anos, 1:400\$000 (um conto e quatrocentos mil réis).

- Sahara, 50 anos, 200\$000 (duzentos mil réis).

- Lúcia, com o filho Carlos, 1:800\$000 (um conto e oitocentos mil réis).

- Sahara, 9 anos, 1:200\$000 (um conto e duzentos mil réis).

- Guilhermina, 4 anos, 400\$000 (quatrocentos mil réis).

Contudo, nenhum caso analisado parece equiparar-se ao desempenho econômico, político e social do pastor Carlos Leopoldo Voges, da Colônia alemã de Três Forquilhas. Seu pragmatismo denuncia-se ao tentar fixar residência definitiva em São Leopoldo em duas ocasiões - 1825/26 e 1831/32 - e no investimento social e financeiro que empreendeu ao longo do século XIX. No âmbito social, apadrinhamentos e casamentos selaram acordos que não só sustentaram as relações de amizade e familiares, como também oportunizaram a realização de negócios; no plano econômico, a aquisição de terras, a construção de moinho e engenho, a compra e manutenção de escravos, a abertura da venda, a sociedade na navegação fluvial colocaram Voges e sua família como um dos grupos "exponenciais" no megaespaço compreendido entre a Colônia-Mãe (São Leopoldo), as colônias situadas no Litoral Norte do Rio Grande do Sul, a Colônia de Taquari e a capital Porto Alegre.

Mesmo que seja difícil rastrear a origem dos escravos de Voges, em algumas situações esse dado transparece. No $3^{\circ}$ Livro de notas do distrito de Maquiné, foi lavrada uma escritura, "aos 20 dias do mês de julho de 1864", na qual ficou registrado que Voges recebeu de Jorge Pessoa da Silva duas escravas como hipoteca, no valor de 4:325\$380, "proveniente de gêneros que o dito Sr. Jorge Pessoa da Silva lhe comprou". O documento, com importante valor histórico, vincula-se à história econômica (do comércio, das vendas, dos negócios), à história da escravidão (nomes e preços de escravos) e à história da imigração (relação dos colonos alemães com a escravidão, comprovando o uso de mão de obra cativa nas Colônias). Afora isso, a escritura de hipoteca informa que Voges fora comerciante até pelo menos 1864, e que os negócios foram vultosos, pois o montante da dívida de Silva chegou a mais de quatro contos de réis. As escravas hipotecadas chamavam-se "Juliana, [com] 17 anos mais ou menos, e Ruffina, [com] 14 anos mais ou menos". ${ }^{14}$

Nesse mesmo ano - 1864 -, no dia 26 de outubro, Voges comprou a escrava Rosária, com a idade de 10 anos "(mais ou menos)", de José Carneiro Lobo, pelo valor de oitocentos mil réis. ${ }^{15}$ Com Juliana, Ruffina e Rosária, as atividades desenvolvidas no conjunto residencial-comercial de Voges foram agigantadas. Como alguns descendentes dos escravos dessa família permaneceram trabalhando em determinadas casas de sobrenome Voges, ao longo do século XX, constata-se que as experiências interétnicas foram vivenciadas por extenso período. Segundo Elio Muller, descendentes de alguns desses escravos permaneceram com a família por muitas décadas, acompanhando o neto do pastor Voges, o líder republicano Cel. Carlos Frederico Voges Sobrinho, por 
toda a sua vida. Embora as relações estabelecidas via escravidão tenham em sua origem um alto grau de violência, outros sentimentos e sensibilidades perpassaram o cotidiano de senhores e escravos - até 1888 - e empregadores e libertos - após a Abolição (MÜLLER, 1992, 1993).

Se a análise da trajetória da família Voges comprova o uso de mão de obra escrava entre colonos alemães do Litoral Norte do Rio Grande Sul, as pesquisas de Marcos Tramontini e Paulo Moreira constatam o mesmo para a Colônia alemã de São Leopoldo. Tramontini (2000, p. 369-372), em sua tese de doutorado, ao investigar os anos iniciais da colonização em São Leopoldo, percebeu que muitos colonos tornaram-se proprietários de escravos. Conforme o autor,

[...] outro índice problemático de crescimento da economia colonial se colocava na compra e utilização da mão de obra escrava, que, ao mesmo tempo, demonstra a hipótese básica desse trabalho, que é a organização social dos imigrantes dentro da dinâmica da sociedade brasileira. Segundo o Censo de 1848, pode-se perceber as atividades econômicas dos colonos que possibilitaram a compra de negros escravos. $\mathrm{Na}$ povoação, eles somavam apenas $7,5 \%$ da população (71 entre 937 habitantes), sendo que 45 pertenciam a alemães e 27 a brasilei$\operatorname{ros}(2000$, p. 369).

Na sequência do texto, Tramontini elencou os nomes e as profissões dos colonos alemães que utilizaram escravos em suas propriedades, rurais ou urbanas. Junto ao nome, o autor listou a quantidade de escravos que cada um possuía. Ao mencionar as leis que regulavam o acesso à terra e à posse de escravos, Tramontini observou que a discussão também girava em torno da ci- dadania dos imigrantes e seus descendentes. Segundo o autor, estes seriam "brasileiros na hora de pagar impostos, de serem recrutados, de obedecerem às leis, mas estrangeiros ou semibrasileiros na hora de usufruírem do direito de posse, de votarem e serem votados, de possuírem escravos" (2000, p. 372). Desse modo, a Lei Imperial no 514 , de 24 de outubro de 1848, e a Lei Provincial $n^{\circ} 183$, de 18 de outubro de 1850, não somente tentaram restringir o acesso dos colonos à mão de obra escrava, como também limitaram sua atuação como cidadãos. No entanto, a listagem dos nomes dos colonos e dos seus respectivos plantéis atesta que ambas as leis foram burladas.

Paulo Moreira e sua equipe de pesquisa, por sua vez, debruçaram-se sobre o $1^{\circ}$ Livro de batismos de escravos da Igreja de Nossa Senhora da Conceição, da freguesia de São Leopoldo. Com essa fonte, foi possível mapear que, em 17 de julho de 1859, o casal Maria e Tomás, escravos de Pedro Schmidt, batizou a filha Isabela e que, em 11 de novembro de 1860, batizou o filho Porfírio. Da mesma forma, o casal Joana e Adão, escravos de Adão e João Diehl, realizou quatro batizados entre os anos de 1860 e 1870 (Timóteo, José Francisco, Andresa e Ana Maria). Destaca-se, em primeiro lugar, que os pais formavam famílias, as quais permaneceram longos períodos com os seus proprietários. Em segundo lugar, os padrinhos de Timóteo foram os escravos Tomás e Eva, posses de Pedro Schmidt. Isso leva a crer que havia comunicação entre essas famílias de cativos, os quais apadrinharam os seus filhos. Os dados levantados por Moreira e sua equipe demonstram que o universo for- 
mado pelos escravos em áreas coloniais era mais dinâmico e complexo. Os batizados realizados pelos dois casais de escravos apontam para certa flexibilização na composição social dos cativos, bem como na possibilidade de comunicação - presencial e oral - nas e entre as Colônias (MOREIRA; MÜGGE, 2012, p. 387-402).

Contabilizando os batismos registrados pelos padres católicos, Moreira e equipe chegaram ao número de 743 entre os anos de 1847 e 1872. Destes, 177 fazem menção a nomes e sobrenomes alemães. Portanto, o número de proprietários desse grupo étnico chegou a representar $24,31 \%$ do total dos batismos (MOREIRA; MÜGGE, 2012, p. 387402). Embora a questão quantitativa seja importante e contribua para a reflexão, o que se quer destacar é o envolvimento dos colonos com a mão de obra escrava e o quanto isso interferiu no cotidiano dos dois grupos. Os batismos, nos quais escravos e senhores poderiam ser convocados para atuar como padrinhos, extrapolam o pragmatismo da compra e venda e denunciam que práticas sociais e religiosas também compuseram o cenário dessas relações. Pastores e acatólicos, bem como padres e católicos efetuaram registros em seus livros e participaram da encenação social e religiosa do batismo com a intenção de inserir a criança nos ritos da sua religião, mas também com o firme propósito de fortalecer os laços entre os agentes históricos ali envolvidos.

No âmbito das relações interétnicas, buscou-se demonstrar que o uso da mão de obra escrava por parte dos imigrantes alemães e seus descendentes integrou-se ao cenário econômico, político, social e, in- clusive, religioso das Colônias. Católicos e acatólicos, mediante suas possibilidades, compreenderam que o uso do trabalho escravo poderia agigantar seus investimentos e inseri-los de forma mais presente e destacada na sociedade hospedeira. Isso remete a uma outra interpretação sobre o processo e/i/migratório. Aproximando escravidão e imigração, relativiza-se a tese do isolamento tanto entre as Colônias quanto entre os colonos alemães e seus descendentes com os nacionais; de igual modo, redireciona-se o holofote dos conceitos de "civilizado", "ordeiro" e "trabalhador" para o agricultor ou artesão que sabe o que quer, que se articula com os pares ou com os outros para buscar o que julga de direito. Pesquisando sobre escravidão e imigração, confirma-se a hipótese de que colonos alemães e seus descendentes inseriram-se na disputa política e/ou disputaram cargos públicos; participaram de conluios, arranjos e fraudes no que se relaciona à prática política; e buscaram assemelhar-se a colonos já mais abastados - "exponenciais" - e, principalmente, aos seus vizinhos nacionais por meio da compra, manutenção e venda de escravos.

\section{Abstract}

The objective of the current text is to establish a dialogue between two relevant themes of the Brazilian historiography-slavery and immigration- under the interethnic relations. In buying and making use of slavery labor, Germans immigrants and descendents equated themselves to the national elite, since to possess slaves would give them a high social status in the nineteenth's 
society. Breaking with the part of historiography about immigration, which affirm that immigrants haven't worked with captives in their properties, wants to demonstrate that the economics, political and social aspects permeated the buying and selling and the maintenance of slavery in rural and urban properties which belong to the immigrants. Inventories, criminal proceedings, the deed for purchase and sale and records elaborated by priests and pastors constitute an important source of studies about the interethnic relations between slaves and German immigrants.

Keywords: Slavery. Immigration. Interethnic relations. XIX Century.

\section{Resumen}

Este texto busca establecer un diálogo entre dos relevantes temas de la historiografía brasileña - la esclavitud y la inmigración - en el entorno de las relaciones interétnicas. Inmigrantes alemanes y sus descendientes se equipararon a la élite nacional al comprar y utilizar la mano de obra esclava, ya que poseer esclavos otorgaba estatus en la sociedad del ochocientos. Rompiendo con parte de la historiografía sobre inmigración, que afirmaba que inmigrantes no habían trabajado con cautivos en sus dominios, se quiere demostrar que aspectos económicos, políticos y sociales atraviesan la compraventa y la manutención de esclavos en propiedades rurales y urbanas de los inmigrantes. Inventarios, procesos criminales, escrituras de compraventa y registros elaborados por sacerdotes y pastores se constituyen en importantes fuentes para el estudio de las relaciones interétnicas entre esclavos e inmigrantes alemanes.

Palabras clave: Esclavitud. Inmigración. Relaciones interétnicas. Siglo XIX.

\section{Notas}

1 Quando escrito com a inicial maiúscula, o termo "Colônia" designa o empreendimento agrícola onde colonos foram assentados, o qual, com o tempo, foi elevado às categorias de vila e cidade. Por sua vez, quando for redigido com a inicial minúscula, "colônia" terá seu significado vinculado à propriedade territorial recebida pelo imigrante onde morou, trabalhou e de onde retirou sua subsistência. Dessa forma, a Colônia era dividida em muitas colônias.

2 A designação "outros" tem como objetivo marcar a diferença entre os imigrantes e a sociedade que, no século XIX, formatava o território brasileiro. De um modo especial, a expressão "outros" vincula-se aos nacionais, grupo composto por descendentes de portugueses e açorianos, aos escravos africanos e a outros agentes históricos que, de alguma forma, já eram fruto da interação entre indígenas, portugueses, espanhóis e escravos africanos.

3 Neste texto, o termo "escravo" refere-se aos africanos escravizados de uma forma geral. Tem-se ciência de que os escravos africanos provinham de inúmeras tribos africanas e que chegaram ao Brasil em períodos distintos, com língua e religião múltiplas. Entretanto, para os propósitos deste texto, não se faz necessário estabelecer distinção entre os escravos provenientes das inúmeras tribos que compunham o cenário multiétnico da África.

4 O termo "Picada" refere-se a uma trilha e/ou uma estrada que foi aberta em meio à mata ou em meio ao campo (dependendo da geografia e da natureza de uma região). Como caminho, dividiu uma extensa propriedade em duas partes, sendo os lotes coloniais medidos à esquerda e à direita a partir da Picada. Com o tempo, essa trilha ou estrada rudimentar tornou-se a principal via de acesso para aquele núcleo colonial. À sua margem, os colonos construíram suas casas, preferencialmente mais próximas da estrada. Muitas 
vezes, o termo "Picada" também designa todo o empreendimento colonial de uma certa região. Via de regra, o nome de um dos primeiros moradores ou de um marco geográfico servem de nome para a Picada. No Vale do Taquari, Eduardo Relly refletiu sobre o conceito de capital social, usando a Picada Felipe Essig como laboratório de investigação (RELLY, 2013).

5 O termo "alemães" será usado de forma genérica e representa os agentes históricos que falavam os inúmeros dialetos dos reinos e principados que, mais tarde, em 1871, formariam a Alemanha. Ellen Woortmann, refletindo sobre o uso do termo "alemães", resume esse impasse: "Aqueles que chegaram eram bávaros, renanos, frísios, saxões, ou mesmo austríacos, franceses e dinamarqueses, todos rotulados como 'alemães'. Como já mencionei, nas 'picadas' organizadas pelo governo brasileiro foram assentados renanos vizinhos de bávaros ou de austríacos, embora em alguns lugares pudessem ter prevalecido migrantes de uma região específica. [...] Essa heterogeneidade resultou numa espécie de 'reinvenção das tradições' sob forma de uma negociação que resultou numa 'tradição teuto-brasileira': dialeto de uma região; hábitos alimentares de outra; religião de uma terceira" (WOORTMANN, 2000, p. 218).

6 O conceito de "exponencial" foi cunhado em minha dissertação para designar os colonos alemães que se destacaram no plano sócio-econômico-político. Como não faziam parte da elite que se originou da imigração e colonização açoriana e portuguesa, optei por conceituá-los dessa forma. Os "exponenciais" identificados e analisados neste trabalho tampouco integram a elite alemã intelectual e/ou de grande destaque econômico, como o jornalista e político Karl von Koseritz. Ao contrário, são personagens de uma camada média que negociava interesses próprios, entremeados com as solicitações dos que estavam socialmente abaixo, com a elite culta e rica tanto nacional quanto alemã (WITT, 2001).

7 O líder espiritual denominado de "pastor" está vinculado à Igreja Evangélica de Confissão Luterana no Brasil (IECLB). Mesmo que a organização dessa instituição tenha ocorrido somente no ano de 1886, com a fundação do Sínodo Rio-Grandense, os pastores que atuaram junto aos imigrantes alemães desde a chegada ao Brasil tinham origem em instituições religiosas alemãs e protestantes. Somente no final do século XIX, com a criação do Sínodo, é que a maioria das comunidades protestantes em solo brasileiro foi reunida sob a forma de uma única igreja. Os imigrantes protestantes também são identificados como acatólicos, ou seja, não católicos. Até 1881, os acatólicos estavam proibidos de professar publicamente a sua fé. Essa situação mudou com a promulgação da Lei Saraiva, a qual deu liberdade de culto e permitiu que os imigrantes e seus descendentes participassem de forma mais ativa da vida política brasileira.

8 A trajetória da parentela Diefenthäler/Voges foi investigada em minha tese de doutorado com o objetivo de mapear as múltiplas atividades econômicas, políticas e sociais dos imigrantes e seus descendentes. Ao longo da pesquisa e da escrita, foi possível esmiuçar o cotidiano dessas duas famílias e como elas buscaram inserir-se na sociedade brasileira. A posse de escravos foi uma das alternativas encontradas pelos familiares Diefenthäler e Voges para enriquecer e ganhar status junto aos nacionais (WITT, 2008).

9 Spliesgart dedicou muitas páginas do seu livro para abordar a questão da escravidão entre imigrantes europeus. Para o autor, os colonos ajustaram-se à nova realidade que os cercava, introduzindo novos costumes ao seu cotidiano. Nesse caso, o uso de trabalhadores escravos foi incorporado ao dia a dia, incrementando a economia e igualando-os aos vizinhos nacionais. (SPLIESGART, 2006, p. 254; p. 285; p. 352; p. 358-359; p. 365-367; p. 474; p. 555).

10 Livro de registro I da comunidade evangélica de Hamburgo Velho (1845-1886), realizado pelo pastor Johann Peter Haesbaert e transcrito por Gaspar Henrique Stemmer, em 1993. Uma das transcrições encontra-se no Museu Histórico Visconde de São Leopoldo. Os registros elencados no presente texto encontram-se nas seguintes páginas do livro transcrito por Stemmer: p. 10; p. 17; p. 21 ; p. 27 ; p. 29-30; p. 34 ; p. 34 ; p. 34 ; p. 38 ; p. 40 ; p. $41 ;$ p. 44 , respectivamente.

11 Dados de identificação do livro: Livro de escrituração de contas correntes - doado ao Museu Histórico Visconde de São Leopoldo - São Leopoldo/RS, pelo Sr. Alfredo J. Diehl - interior de Osório - registros de 1874 a 1901. O referido livro tem 608 páginas, das quais foram usadas 353 . No final, tem-se o índice alfabético no qual foram descritos os nomes dos fregueses com as respectivas páginas. Como acervo, o documento está em perfeitas condições de manuseio e impressiona por suas características: capa dura, papel de boa qualidade e esmero na fabricação.

12 Arquivo Público do Estado do Rio Grande do Sul (APERS) - Inventário de Guilhermina Voges - Inventariante: Adolpho Felippe Voges - Autos 195 - maço 6 - estante 62 - 1880 - Conceição do Arroio - Cartório de Órfãos e Ausentes. 
13 Segundo Pellanda, esses números geravam controvérsia, pois nem todos aceitavam a contagem apresentada nos relatórios oficiais. No entanto, a título de ilustração, usaram-se os números sugeridos pelo autor (PELLANDA, 1925, p. 61-64).

14 APERS - $3^{\circ}$ Livro de notas do distrito de Maquiné - Conceição do Arroio.

15 APERS - Escrituras de escravos de Conceição do Arroio - ano 1864.

\section{Referências}

BRAUN, Felipe Kuhn. História da imigração alemã no Sul do Brasil. 2. ed. Porto Alegre: Costoli, 2010.

DREHER, Martin Norberto. O fenômeno imigratório alemão para o Brasil. Estudos Leopoldenses, São Leopoldo: Ed. da Unisinos, v. 31, n. 142, p. 59-82, maio/jun. 1995.

FARINATTI, Luís Augusto Ebling. Nos rodeios, nas roças e em tudo o mais: trabalhadores escravos na campanha rio-grandense (1831-1870). In: ENCONTRO NACIONAL "ESCRAVIDÃO E LIBERDADE NO BRASIL MERIDIONAL", 2 ., 2005, Porto Alegre. Disponível em: <http:// www.escravidaoeliberdade.com.br/site/images/Textos2/luiz $\% 20$ augusto $\% 20$ farinati $\% 20$ completo.pdf>. Acesso em: 15 jul. 2013.

GANS, Magda Roswita. Presença teuta em Porto Alegre no século XIX. Porto Alegre: Ed. da UFRGS; Anpuh/RS, 2004.

GIRON, Loraine Slomp; RADÜNZ, Roberto. Invisíveis: negros nas memórias dos brancos. Revista Brasileira de História e Ciências Sociais, v. 4, n. 7, p. 143-161, jul. 2012.

GONÇALVES, Dilza Porto. A memória na construção de identidades étnicas: um estudo sobre as relações entre "alemães" e "negros" em Canguçu. 2008. Dissertação (Mestrado em História) - Programa de Pós-Graduação em História - Pontifícia Universidade Católica do Rio Grande do Sul - PUCRS, Porto Alegre, 2008.

LEVI, Giovanni. A herança imaterial: trajetória de um exorcista no Piemonte do século XVII. Rio de Janeiro: Civilização Brasileira, 2000.
MAGALHÃES, Magna Lima. Entre a preteza e a brancura brilha o Cruzeiro do Sul: associativismo negro em uma localidade teuto-brasileira. In: FERNANDES, Evandro et al. (Orgs.). Imigração: diálogos e novas abordagens. São Leopoldo: Oikos, 2012. p. 84-90.

MOEHLECKE, Germano Oscar. O colono alemão e o negro. In: RAMBO, Arthur B. (Org.). Anais do VIII e IX Simpósios de História da Imigração e Colonização Alemãs no Rio Grande do Sul. Nova Petrópolis: Amstad, 1998. p. 56-65.

MOREIRA, Paulo; MUGGE, Miquéias Henrique. Negros em terras de alemães: escravos e libertos em zona de imigração europeia Stumpf, Schneider e seus escravos. In: BARROSO, Véra Lucia Maciel et al. (Orgs.). Raízes de Nova Hartz. Novo Hamburgo: Um Cultural, 2012. v. II. p. 387-402.

MÜLLER, Elio Eugenio. Três Forquilhas (18261899). Fase de formação da colônia. Curitiba: Fonte, 1992.

Três Forquilhas (1900-1949). Tempos de República. Curitiba: Italprint, 1993.

MÜLLER, Telmo Lauro. Negros de fala alemã. In: FISCHER, Luís Augusto; GERTZ, René E. (Orgs.). Nós, os teuto-gaúchos. Porto Alegre: Ed. da UFRGS, 1996. p. 238-23.

NUNES, Margarete Fagundes. A cidade, a diversidade etnicorracial e os jogos de memória. In: FERNANDES, Evandro et al. (Orgs.). Imigração: diálogos e novas abordagens. São Leopoldo: Oikos, 2012. p. 91-103.

OLIVEIRA, Vinicius Pereira de. De Manoel Congo a Manoel de Paula: um africano ladino em terras meridionais. Porto Alegre: EST, 2006.

OSÓRIO, Helen. Campeiros e domadores: escravos da pecuária sulista, século XVIII. In: ENCONTRO NACIONAL "ESCRAVIDÃO E LIBERDADE NO BRASIL MERIDIONAL", 2., 2005, Porto Alegre. Disponível em <http:/ / www.escravidaoeliberdade.com.br/site/images/Textos $2 /$ helen $\% 20$ osrio \% 20completo. pdf>. Acesso em: 16 jul. 2013. 
PELLANDA, Ernesto. A colonização germânica no Rio Grande do Sul. Porto Alegre: Oficinas Gráficas da Livraria do Globo, 1925.

PICCOLO, Helga Iracema Landgraf. Escravidão, imigração e abolição. Considerações sobre o Rio Grande do Sul do século XIX. In: REUNIÃO DA SOCIEDADE BRASILEIRA DE PESQUISA HISTÓRICA (SBPH), 8., 1989, São Paulo. Anais... São Paulo: SBPH, 1989. p. 53-62.

Século XIX: alemães protestantes no Rio Grande do Sul e a escravidão. In: REUNIÃO DA SOCIEDADE BRASILEIRA DE PESQUISA HISTÓRICA (SBPH), 8., 1989, São Paulo. Anais... São Paulo: SBPH, 1989. p. 103107.

RELLY, Eduardo. Floresta, capital social e comunidade: imigração e as picadas teuto-brasileiras (1870-1920). 2013. Dissertação (Mestrado em Meio Ambiente e Desenvolvimento) - Programa de Pós-Graduação Stricto Sensu - Centro Universitário UNIVATES, Lajeado, 2013.

SEYFERTH, Giralda. Imigração, colonização e a questão racial no Brasil. Revista USP, São Paulo: USP, n. 53, p. 117-149, mar./maio 2002.

SPERB, Angela. O inventário de João Pedro Schmitt. In: SIMPÓSIO DE HISTÓRIA DA IMIGRAÇÃO E COLONIZAÇÃO ALEMÃ NO RIO GRANDE DO SUL, 4., 1987, São Leopoldo. Anais... São Leopoldo, 1987, p.17-44.

SPLIESGART, Roland. "Verbrasilianerung" und Akkulturation. Deutsche Protestanten im brasilianischen Kaiserreich am Beispiel der Gemeinden in Rio de Janeiro und Minas Gerais (1822-1889). Wiesbaden: Harrassowitz Verlag, 2006.

TRAMONTINI, Marcos Justo. A organização social dos imigrantes. São Leopoldo: Ed. da Unisinos, 2000.

WEBER, Regina. Imigração e identidade étnica: temáticas historiográficas e conceituações. Revista Dimensões, v. 18, p. 236-250, 2006.
WITT, Marcos Antônio. Política no Litoral Norte do Rio Grande do Sul: a participação de nacionais e de colonos alemães - 1840-1889. Dissertação (Mestrado) - Programa de Pós-Graduação em História, Universidade do Vale do Rio dos Sinos - Unisinos, São Leopoldo, 2001.

Em busca de um lugar ao sol: estratégias políticas. São Leopoldo: Oikos, 2008.

WOORTMANN, Ellen Fensterseifer. Identidades e memória entre teuto-brasileiros: os dois lados do Atlântico. Horizontes Antropológicos, Porto Alegre: UFRGS, ano 6, n. 14, p. 205-238, nov. 2000. 